\title{
Starcy Pustelni Optyńskiej i rosyjska inteligencja XIX wieku
}

\author{
Tomasz Kuprjanowicz \\ Chrześcijańska Akademia Teologiczna w Warszawie \\ Warszawa, Polska \\ t.kuprjanowicz@interia.pl
}

T. Kuprjanowicz, The Elders of the Optina Monastery and the Russian Intelligence of the 19th Century, Elpis, 20 2018: 129-133.

\begin{abstract}
This article provides an explanation of the meaning of the word "elder" (starets) used in reference to the monks of the Optina Monastery on the basis of the Tradition of the Orthodox Church as a word understood not in the sense of physical age, but in the sense of perfect spiritual and moral growth. The article also shows the worldview of the Russian Intelligence of the 19th century and the benevolent influence the Elders of the Optina Monastery had on it.
\end{abstract}

Streszczenie: W artykule wyjaśnione zostało znaczenie słowa „starzec” stosowanego w odniesieniu do mnichów optyńskich na podstawie Tradycji Prawosławnej jako słowa rozumianego nie w sensie fizycznej starości, ale w sensie doskonałego wzrostu duchowo-moralnego. W artykule ukazany jest również światopogląd rosyjskiej inteligencji XIX w. i dobroczynny wpływ na niego Starców Pustelni Optyńskiej.

Keywords: Elders, Optina Monastery, Russian Intelligence

Slowa kluczowe: Starcy, Monaster Optyński, Rosyjska Inteligencja

„Rosyjskie starczestwo w osobie św. Ambrożego oraz innych starców optyńskich wywarło poważny wpływ na wielu ludzi. Przenikliwość, mądrość, miłość do ludzi i duchowa siła czyniły ich znanymi w całej Rosji. Z różnych stron przybywali do nich biedni i bogaci, inteligencja i prości ludzie" - pisał patriarcha Aleksy II [Алексий II 2006].

„Pobożni starcy byli posiadaczami i nosicielami łaski Bożej, która pokrzepiała i wzmacniała dusze przychodzących do monasteru. Wielu z tych, którzy zwracali się do nich o pomoc, poprzez poradę i uspokojenie mogło tymczasowo uciec od pokus i namiętności dzięki ich modlitewnej pomocy. Relacje z nimi dawały ludziom możliwość wzięcia udziału w uzdrawiającym i pokrzepiającym działaniu łaski Bożej, która lekka jak powietrze, potrzebna jest każdemu ludzkiemu sercu" - słowa metr. kałuskiego i borowskiego Klemensa [Климент 2006, 22].

Zgodnie z myślą metr. Tryfona (Turkiestanowa) idea starczestwa „należy do tych najbardziej duchowych, tj. określających warunki potrzebnych do chrześcijańskiego życia, możliwego tylko na łonie Cerkwi prawosławnej" [Трифон 1996, 22]. Uważa on, że idea starczestwa pochodzi z ksiąg Starego Testamentu, od pierwszego rozdziału Księgi Rodzaju i pojawienia się Zbawiciela. Pierwszym przedstawicielem starczestwa nazywa on pojawiającego się na przełomie dwóch Testamentów św. Jana Chrzciciela [Трифон 1996, 40, 87].

Nie jest znana dokładna data pojawienia się starczestwa, choć powinno ono było rozkwitać w starożytnych, egipskich i palestyńskich ośrodkach cenobitycznych. Starczestwo narodziło się za sprawą starożytnego, chrześci- jańskiego światopoglądu ascetyczno-mistycznego. Stało się podstawą dyscypliny monasterskiej i duchowej strawy przyszłych mnichów [Смолич. Русское... 1997, 323; Соколов, 14].

„Słowo «starczestwo» pochodzi od słów «starość» i «starzec», rozumianych nie w sensie fizycznej starości, ale $\mathrm{w}$ sensie doskonałego wzrostu duchowo-moralnego $(E f 4,13)$ [Соколов, 6]. „Starzec” - to człowiek niemłody wiekiem, ale przede wszystkim człowiek, który prowadzi życie duchowe na wysokim poziomie i który pracował nad sobą pod przewodnictwem innego starca, nad „rozwojem i wzmocnieniem swojego rozumu w poznaniu ewangelicznej prawdy, swojego serca - w miłości chrześcijańskiej i swojej woli - w pokorze i posłuszeństwie. Dzięki temu zdobył duchowe doświadczenie i błogosławioną zdolność do przewodzenia innym na trudnej i ciernistej drodze do duchowej doskonałości" [Соколов, 6].

„Zadanie starca polegało na przewodzeniu duszy i woli młodego mnicha... zadanie to było nadzwyczaj odpowiedzialne; posłuszeństwo wobec starca było niełatwe dla początkującego. Starzec, przyjmując młodego mnicha na posłuszanije, kładł na siebie ciężki krzyż" - krzyż wielkiej cierpliwości i pokory [Смолич. Русское... 1997, 323-324].

Zasadniczym i trudnym zagadnieniem w chrześcijańskiej ascetyce jest zrozumienie tego, że w „wyrzeczeniu się wszelkiej ziemskości" nie ma odrzucenia świata. Celem nie jest pełne umartwianie ciała, lecz jego pokonanie i przemiana, ,jedność z Bogiem”. Asceta, który osiągnie taki stan, pokona ziemskie namiętności i zostanie świętym, powraca do świata i służy swoim bliźnim. Jest to zasad- 
niczym celem aktywnego ascetyzmu [Смолич. Жизнь... 1997, 371].

W badaniach nad staroruskim starczestwem trudność polega na wieloznaczności słowa „starzec”. Przede wszystkim oznaczało ono starszego mnicha, który nie ma stanu kapłańskiego. Tym samym nazywano „soborowymi starcami" tych mnichów, którzy wraz z namiestnikiem zarządzali monasterem. Określenie „starzec’ mogło być nadawane także namiestnikom. „Starcami” nazywano mnichów, którzy zajmowali się duchowym kierownictwem posłuszników. Stopniowo słowo „starzec” było najczęściej używane w sensie: ,jeden ze starszych mnichów, który przeszedł ciężką drogę samozaparcia i który wziął pod swe duchowe przewodnictwo młodych mnichów i świeckich" [Смолич. Жизнь... 1997, 376; Смолич. Русское... 1997, 328]. D. D. Sokołow podkreśla „ogromne znaczenie pedagogiczne i moralne starczestwa także dla świeckich ludzi" [Соколов, 13].

Metr. Tryfon pisze, że osiągnięcie głównych cnót chrześcijańskich przez przewodnictwo starca jest niełatwe. Dusza poprzez pokutę zaczyna widzieć, słyszeć i rozumieć. Pokuta niemożliwa jest zaś bez pokornej mądrości (smirennomudrija) wspieranej przez wykonywanie poleceń (postuszanije) oraz umęczenia ciała trudami ascetycznymi. Dlatego... powinniśmy powierzyć siebie tym nauczycielom i przewodnikom, którzy... rozumiejąc ją poprzez swe własne doświadczenie, mogą nauczyć jej także nas" [Трифон 1996, 49-50]. „Wraz ze zmniejszeniem się ilości starców... nie skupiamy większej uwagi na wewnętrznym trudzie modlitewnym, który stanowi całą istotę duchowego życia, a którego celem jest ścisła relacja z Bogiem. ... Starczestwo, które rozkwitało w tym stuleciu w Pustelni Optyńskiej jest najlepszym dowodem jego przydatności. Dało ono licznych i wielkich duchem mnichów, przyczyniło się do rozkwitu literatury ascetycznej, a w osobie słowianofilów zbliżyło wykształcone społeczeństwo z prawosławnym monastycyzmem. Wreszcie zachęciło moralnie, nadało nową jakość życia i wyznaczyło cele tysiącom cierpiących dusz. Czyż nie jest to najlepszy dowód prawdziwości starczestwa?" [Трифон 1996, 21].

Podczas służby starców w świecie rosyjski monastycyzm tracił właściwą dla niego zamkniętość. Zaczęło się od ascetycznej szkoły o. Paisjusza Wieliczkowskiego, która nakarmiła duchowością niemal wszystkich starców. Początkowo ona sama miała zamknięty charakter, lecz z czasem zaczęła służyć nie tylko mnichom, ale także ludziom żyjącym w świecie. „Tym sposobem ascetyczna tradycja Cerkwi Wschodniej w rosyjskim starczestwie przyjęła nową formę. Nastąpiło to samo z siebie, bez jakiegokolwiek ruchu ze strony władzy cerkiewnej... Sama istota starczestwa doprowadziła do tego, że stopniowo odnowiono duchowe pokrewieństwo między mnichami i ludem" [Смолич. Русское... 1997, 367].

Światopogląd w życiu człowieka i narodu ma kluczowe znaczenie. Toteż można zrozumieć, dlaczego w całej późniejszej historii państwa rosyjskiego z takim napięciem współzawodniczą ze sobą sprzeczne idee: „,czy Rosja w celu wypełnienia swej historycznej misji powinna naj- pierw chronić swoją kulturową osobliwość i duchową tożsamość zakorzenioną w Prawosławiu, czy raczej powinna stać się w pełni europejskim krajem na obraz i podobieństwo innych?" [Осипов 2007, 69].

W obliczu procesu sekularyzacji i towarzyszącemu mu procesowi rozpadu duchowej kultury chrześcijańskiej to właśnie Rosja jest ojczyzną dziedziców tej kultury, którym udało się przyswoić ,zasadnicze struktury tego doświadczenia ludzkiego istnienia, które uwarunkowało tę kulturę" [Антонов 2006, s. 6]. Świadomy zwrot ku tradycji i pokonanie zaburzającego wpływu idei oświecenia ma miejsce także dzisiaj, gdy proces sekularyzacji zaszedł tak daleko, że postawił pod znakiem zapytania samo istnienie ludzkości. Ma on szczególne znaczenie, większe niż w XIX w., gdy rosyjska myśl intelektualna odnalazła zdecydowany powrót do Cerkwi [Антонов 2006, 6]. ,Jednakże - jak pisze K. M. Antonow - ...powrót ten dokonywał się od tej pory nie tylko w Rosji. Można tu prędzej mówić o pewnym decydującym wydarzeniu w duchowej historii ludzkości, o projekcie historycznym, nie mniej fundamentalnym niż projekt oświecenia, lecz skierowanym w przeciwną stronę. To projekt religijnego odrodzenia, który dokonywał się przy pomocy filozofii" [Антонов 2006, 7]. Wielka rola tego wydarzenia $\mathrm{w}$ procesie powrotu była zdeterminowana przez szereg przyczyn. Powstająca kultura sekularna wymagała rozwiniętego umysłu. Wymagała także przemyślanych osiągnięć. Człowiek powracający z ateizmu do życia religijnego miał potrzebę filozoficznego uświadomienia sobie swego doświadczenia i swego nowego stylu życia. Pojawiła się także potrzeba świadomości biegu historycznego [Антонов 2006, 7-8].

„Każde zjawisko w życiu społecznym i każde odkrycie w naukach znajduje się w umyśle człowieka daleko od granic jego widzialnej sfery. Wiązanie go z zagadnieniami ogólnoludzkimi osiąga znaczenie racjonalno-filozoficzne. Wszelka uniwersalność zdarzeń społecznych pomaga takiemu kierunkowi umysłowemu... Pojawianie się nowych systemów filozoficznych kończyło się, lecz władza filozofii racjonalnej trwa dalej” - pisał I. W. Kiriejewski [Киреевский. О необходимости... 2002, 216].

Ostateczny sens każdej filozofii zawiera się nie w odrębnych prawdach, lecz na takiej postawie, w której pokaże człowiekowi ostateczną prawdę i wewnętrzną potrzebę, która ją określa. Ta ostateczna prawda wskaże człowiekowi jego największy skarb. „Na końcu systemu filozoficznego, między jego odwieczną prawdą i odwiecznym celem nie leży już myśl mająca określoną formę, lecz jeden tzw. duch myśli, jej wewnętrzna siła i jej najgłębsza muzyka, która towarzyszy wszystkim ruchom duszy człowieka przekonanego o niej... System należy do szkoły; jego siła i ostateczna potrzeba należy do życia i oświecenia całej ludzkości" [Киреевский. О необходимости... 2002, 231-232].

Kiriejewski pisze, że europejska oświata różni się od charakteru oświaty prawosławnej, aczkolwiek niewiele. W jej istocie znajduje się konieczność niektórych okresów rozwoju, choć między nimi ,jest ona wolna od poprzednich wpływów i zdolna do wyboru tego czy innego kierunku" [Киреевский. О необходимости ... 2002, 243]. 
W Kościele Zachodnim charakter panującej filozofii jest określany charakterem panującej wiary. Człowiek rozumie prawdę tylko $\mathrm{w}$ tym sensie, $\mathrm{w}$ jakim rozumiał Boskość [Киреевский. О необходимости... 2002, 245]. W Cerkwi prawosławnej stosunek między rozumem i wiarą jest inne niż w Kościele rzymskim i wyznaniach protestanckich. „W Cerkwi prawosławnej Objawienie Boże i ludzkie myślenie nie mieszają się ze sobą. Granice między Boskością i ludzkością nie są naruszane ani poprzez naukę, ani nauczanie Cerkwi. Jeżeli wierzący sposób myślenia spróbuje $\mathrm{w}$ jakiś sposób pogodzić rozum $\mathrm{z}$ wiarą, to nigdy nie uzna on żadnego dogmatu Objawienia za prosty wniosek rozumu, a także nigdy nie nada wnioskowi rozumu autorytetu dogmatu objawionego. Granice są twarde i nienaruszalne" [Киреевский. О необходимости... 2002, 246]. Kiriejewski stwierdza dalej, że „im wyraźniejsze i twardsze są granice Bożego Objawienia, tym silniejsza jest potrzeba wierzącego myślenia - pogodzić pojęcie rozumu z nauką wiary. Ponieważ prawda jest jedna, a dążeniem do uświadomienia sobie tej jedności jest stałe prawo i zasadnicze pobudzenie pracy rozumu" [Киреевский. О необходимости... 2002, 247-248].

Główną różnicą w myśleniu prawosławnym jest to, że nie ustala ono po prostu poszczególnych pojęć w zgodzie z regułami wiary, lecz próbuje wznieść cały rozum ponad ogólny poziom, a sam sposób myślenia doprowadzić do zgody z wiarą. Zasadniczym warunkiem do spełnienia tego jest to, aby rozum dążył do zebrania wszystkich sił w jedną całość oraz to, aby nie uważał zdolności do logicznego myślenia za jedyny sposób rozumienia prawdy. „Podczas całkowitego myślenia wszystkie struny duszy przy każdym poruszeniu powinny być słyszane w pełnej jakości dźwięku, tworząc jedno harmoniczne brzmienie" [Киреевский. О необходимости... 2002, 249]. „Prawosławny wierny wie, że do pełnej prawdy potrzebna jest całość rozumu, a poszukiwanie tej całości jest stałym zadaniem tego myślenia" [Киреевский. О необходимости... 2002, 250].

Myślenie prawosławnego wiernego zawsze składa się z podwójnej działalności: śledzi on swoje rozumowanie i sposób swego myślenia, stale podnosząc swój rozum do wspólnego poziomu z wiarą [Киреевский. $O$ необходимости... 2002, 252]. „Filozofia nie jest jedną z nauk i nie jest wiarą. Stanowi ogólny rezultat, ogólną podstawę wszystkich nauk i przekaźnik między nimi i wiarą. Tam, gdzie jest wiara i nie ma rozwoju edukacji rozumu, tam także nie może być filozofii”" [Киреевский. О необходимости... 2002, 253].

Przekonania wiary prawosławnej u ludzi, jak pisze Kiriejewski, nie idą $\mathrm{w}$ parze $\mathrm{z}$ edukacją, która jest zapożyczona. Zadaniem, które może zmienić w ludziach kierunek oświecenia jest jego zdaniem przeciwstawienie „drogocennych i życiowych prawd", wyrażonych w pismach świętych ojców i stanowisku filozofii. „Wszystko, co jest istotne w duszy człowieka, wzrasta w nim tylko społecznie... Niezbędne jest to, aby osobiste przekonania nie były tylko przypuszczalnym, ale rzeczywistym spotkaniem z pytaniami otaczającej oświaty. Dlatego, że tylko z właściwego stosunku do rzeczywistości rodzą się te myśli, które oświecają umysł i ogrzewają duszę" [Киреевский. $O$ необходимости ... 2002, 255]. Wzniosła i ożywiająca siła rozumu pochodzi nie od myśli, która jest mu podporządkowana, lecz z jego wewnętrznego stanu schodzi na myśl, „w której odnajduje spokój i poprzez którą nawiązuje relacje z innymi osobami” [Киреевский. О необходимости... 2002, 267]. Kiriejewski dochodzi do wniosku, że samodzielna rosyjska mądrość, odpowiadająca podstawowym zasadom staroruskiej edukacji, może podporządkować „rozdwojoną edukację Zachodu pełnej świadomości wierzącego rozumu" [Киреевский. О необходимости... 2002, 268].

Ks. prot. Jerzy Florowski pisał: „Historia Słowian może osiągnąć kulturową wartość wyłącznie poprzez wolne podporządkowanie sobie ludzi ogólnoludzkimi ideami o charakterze uniwersalnym" [Флоровский 1998, 50]. Jak podkreśla: „Lud jest tylko nosicielem. To nie biologiczna afirmacja, lecz emocjonalna świadomość bezwarunkowej wartości uniwersalnego daru wręczonego słowiaństwu daje prawo do istnienia własnej, osobliwej kultury wschodnio-słowiańskiej. Tylko wtedy historia stanowi odpowiedzialny trud urzeczywistnienia Prawdy Bożej, a nie tylko spontaniczny proces walki o przetrwanie gatunku. Środek ciężkości spoczywa nie na słowiańskich, lecz prawosławnych cechach. Jednakże Prawosławie nie jest cechą, na równi z innymi, lecz pełnią, od której „odłączyły się inne, istotne cechy" [Флоровский 1998, 263]. Na przestrzeni całej historii „utrata i przywrócenie normalnych relacji człowieka z Bogiem stanowią główne punkty sporne procesu historycznego... Pomijając upadek, dążenie do Boga zachowało się w człowieku jako określona cecha jego natury" - zauważa K. M. Antonow [Антонов 2013, 26]. Tylko Prawosławie może dać człowiekowi duchową wartość, jako jedyne, prawdziwe i nieskażone chrześcijaństwo, jak pisze W. A. Nikitin [Никитин 2007, 126]. W stosunku do duchowej drogi Rosji i na podstawie analizy twórczości I. W. Kiriejewskiego dochodzi on do wniosku: „Wyłącznie zwrócenie się ku Prawosławiu, pełne i wszechstronne ofiarowanie Cerkwi narodowej oświaty i kultury wyeliminuje to duchowe rozdwojenie, na które cierpi rosyjskie, wykształcone społeczeństwo od czasów reform Piotra I" [Никитин 2007, 126].

Patriarcha Aleksy II podkreślał, że odrodzenie rosyjskiego kraju jest niemożliwe bez powrotu do kulturowego i duchowego dziedzictwa. Pisał: „Od duchowego wyboru inteligencji i całego społeczeństwa w pełni zależą przyszłość Rosji, jej bezpieczeństwo i życie przyszłych pokoleń” [Алексий II 2006]. Jednakże rola rosyjskiej inteligencji jest bardzo niejednoznaczna, jak mówi K. A. Tatarski. „Wchodząc coraz głębiej w epokę oświecenia, staje się ona owocem późnego okresu rozwoju Rosji. Rosyjska inteligencja często była posądzana o bezreligijny idealizm i racjonalizm oraz zerwanie $\mathrm{z}$ duchowymi tradycjami narodu" [Татарский 2006, 48]. Jednakże w historii Rosji mamy również taką inteligencję, która w swej twórczej służbie narodowi i Rosji dążyła do poznania Boga. Dała ona światu twórców - założycieli wielkiej kultury, u podstaw której leżała duchowość. Wyrażała ona ideę prymatu 
duchowo-moralnego ideału w stosunku do społeczeństwa [Татарский 2006, 48].

Patriarcha Aleksy II zwracał uwagę na dwa aspekty historii Rosji XIX wieku: „duchowy rozkwit rosyjskiego starczestwa oraz powrót części rosyjskiej inteligencji do nauki świętych ojców i prawosławnej tradycji cerkiewnej” [Алексий II 2006]. Patriarcha podkreślał, że charakterystyczną cechą XIX stulecia był „wybór rosyjskiego społeczeństwa: powrót do duchowego dziedzictwa swoich przodków lub podążanie za niezgodną naukę, co jest w ogóle przeciwne Prawosławiu" [Алексий II 2006]. W XIX w. rosyjska inteligencja w większości była prawosławna, choć istniały różne kręgi i nurty, spośród których wyróżniało się słowianofilstwo i okcydentalizm [Климент 2007, 27].

Władyka Klemens (Kapalin) twierdzi, że istniejące mniemanie o tym, że przed rewolucją inteligencja sprzeciwiała się Cerkwi jest fałszywe. Tacy jej przedstawiciele byli w mniejszości. „Z pewnością nie można zaprzeczyć, że wśród inteligencji byli i tacy, który oponowali Cerkwi. Przyczyną tego było niezrozumienie przeznaczenia i natury Cerkwi prawosławnej. Mogli to być także ludzie, którym obce były duchowe tradycje Rosji... Nie mniej jednak zawsze była część inteligencji, która interesowała się zagadnieniami duchowego życia i brała aktywny udział w życiu Cerkwi [Климент 2007, 27]. Duchowe poszukiwania rosyjskiej inteligencji wyrażone poprzez rozwój filozoficzny w latach trzydziestych i czterdziestych XIX w. miały podwójne źródło. „Dla jednych została odkryta droga do Cerkwi, droga religijnego odrodzenia - religijna apokatastaza myśli i woli. Dla drugich była to droga do niewiary, a nawet do otwartej walki z Bogiem. Ten podział lub polaryzacja rosyjskiej elity kulturowej następowały właśnie na poziomie religijnym" [Флоровский 1983, 246].

W. S. Głagolew wiąże pojęcie inteligencji z pojęciami kultury piśmiennej i książkowej, która istniała jeszcze na dawnej Rusi, jednakże wtedy była obecna przede wszystkim wśród mnichów. Jak pisze: „Skok ilościowy we wzrastającej liczbie ludzi wykształconych i kulturalnych wyprowadza książkowe, symboliczne sposoby socjalizacji z ograniczonej sfery działalności cerkiewno-religijnej i państwowej... czyniąc z nich własność rozszerzających się grup populacji” [Глаголев 2006, 196]. Następuje sekularyzacja tych sposobów socjalizacji, a ich duchową treść wypełnia świecka sztuka, literatura oraz poszukiwania moralno-filozoficzne i świecko-religijne. „Pod ich wpływem odkrywa się wielka kultura rosyjska XIX wieku... Rola inteligencji $\mathrm{w}$ tych procesach wzrasta nie tylko do rangi masowego konsumenta i popularyzatora, ale także wrażliwego kamertonu, który określa liczne drogi twórczości literackiej i artystycznej” [Глаголев 2006, 196]. Zarówno jako konsumenci, jak i twórcy przywiązują się do tej twórczości ludzie różnych, masowych zawodów: nauczyciele, prawnicy, lekarze i urzędnicy.

W drugiej połowie XIX w. tendencje te aktywują się. „Rosja staje się czytająca, teatralna, muzykalna i zamyślona o treściach zagadnień filozoficznych, naukowych, moralnych i religijnych" [Глаголев 2006, 196]. W. S. Głagolew określa cechy typowe dla inteligencji i pozwalające mówić o możliwości „translacji duchowej kultury”: krytyczność, konstruktywność (wyznaczenie perspektyw rozwiązania problemu), uczciwość, poczucie realizmu i czułość. „W rosyjskiej tradycji czułość wiąże się z głęboką potrzebą duchową, aby podążać za wzorem życia i nauczaniem Jezusa Chrystusa, Apostołów, Ewangelistów oraz rosyjskich świętych i ascetów" [Глаголев 2006, 197]. Ważnym elementem rosyjskiej inteligencji jest sekwencja wypełniania podstawowego zadania, któremu poświęca następne półtora stulecia -zadania „przetrwania narodu”. Tym sposobem W. S. Głagolew uważa, że zasadniczym kierunkiem inteligencji $\mathrm{w}$ jej duchowej pracy $\mathrm{i} \mathrm{w}$ istocie przez nią wybranym jest służba narodowi [Глаголев 2006, 199]. Ten sam kierunek działalności urzeczywistnia się w monastycyzmie, a szczególnie w starczestwie.

Metropolita kałuski i borowski Klemens zaznaczył, że to właśnie monaster Wprowadzenia Bogurodzicy do Świątyni w Pustelni Optyńskiej i jego starcy stali się zbawczym schronieniem dla Rosji i wielu ich przodków, którzy utracili autentyczne punkty orientacyjne skierowane na poszukiwanie Królestwa Bożego [Климент 2006, 22]. Na przestrzeni długiego okresu czasu Optyna ,przyciągała do siebie ludzi nauki i kultury, a żyjący tam starcy, nauczeni mądrości życiowego i duchowego doświadczenia, zawsze byli otwarci na pytających. Dlatego wykształciło się tam swego rodzaju centrum dialogu między starcami-mnichami i inteligencją" [Климент 2007, 27]. Do Optyny mógł przyjść każdy i dowiedzieć się czego mu potrzeba, aby skierować swoje życie na drogę prawdy. Przez sto lat optyńskiego starczestwa przebywali w monasterze prawie wszyscy znani przedstawiciele rosyjskiej inteligencji. Wielu z nich nie było zwykłymi mieszkańcami monasteru, lecz duchowymi dziećmi ich starców [Климент 2007, 27]. „Optyna dla Rosji XIX wieku była mocnym murem, w zetknięciu z którym fale niewiary i nihilizmu, ogarniające i pochłaniające znaczną część tzw. «oświeconego» społeczeństwa, traciły swoją destrukcyjną mос" [Климент 2006, 22].

\section{Bibliografia}

Алексий II, Патриарх Московский и всея Руси. Приветствие I Оптинскому форуму // I Оптинский форум. Наследие России и духовный вы-бор российской интеллигенции. Калуга - Оптина пустынь, 19-21 мая 2006 г.: Сб. материалов. М.; Калуга, 2006.
Антонов К.М. Философия И.В. Киреевского: антропологический ас-пект. М.: Изд-во ПСТГУ, 2006.

Антонов К.М. Философия религии в русской метафизике ХІХ - начала ХХ века. М.: Изд-во ПСТГУ, 2013.

Глаголев В.С. Опыт русской интеллигенции в трансляции ду- 
ховной культуры // I Оптинский форум. Наследие России и духовный выбор российской интеллигенции. Калуга Оптина пустынь, 19-21 мая 2006 г.: Сб. материалов. М.; Калуга, 2006. С. 195-200.

Киреевский И.В. О необходимости и возможности новых начал для философии // Киреевский И.В. Разум на пути к истине. М.: Правило веры, 2002. С. 214-268.

Климент (Капалин), митрополит Калужский и Боровский. Выступление на открытии I Оптинского форума // I Оптинский форум. Наследие России и духовный выбор российской интеллигенции. Калуга - Оптина пустынь, 19-21 мая 2006 г.: сб. материалов. М.; Калуга, 2006. C. 21-24.

Климент (Капалин), митрополит Калужский и Боровский. Выступление на открытии II Оптинского форума // II Оптинский форум. Наследие России и духовный выбор российской интеллигенции. Москва - Калуга - Оптина пустынь, 18-21 мая 2007 г.: сб. материалов. В 3 т. М.; Калуга, 2007. Т. 1. С. 25-29.

Никитин В.А. Актуальность „Русской идеи” Ивана Киреевского // Иван Киреевский. Духовный путь в русской мысли XIX-XXI вв. (К 200-летию со дня рождения): сб. науч. ст. М., 2007.

Осипов А.И. Россия сегодня и славянофилы // Иван Киреевский: Духовный путь в русской мысли XIX-XXI вв.
(К 200-летию со дня рож-дения): сб. науч. ст. М., 2007. С. 61-76.

Смолич И.К. Жизнь и учение старцев // Смолич И.К. Русское монаше-ство 988-1917. Жизнь и учение старцев. Приложение к „Истории Русской Церкви”. М.: Церковно-научный центр «Православная энцикло-педия”, 1997. С. 369-464.

Смолич И.К. Русское монашество 988-1917 // Смолич И.К. Русское монашество 988-1917. Жизнь и учение старцев. Приложение к „Истории Русской Церкви”. М.: Церковно-научный центр „Православная энциклопедия”, 1997. С. 11-368.

Соколов Д.Д. Оптинское старчество и его влияние на монашествующих и мирян. Б.м.: Издательство Свято-Введенской Оптиной Пустыни, (bez roku wydania)

Татарский К.А. Сила России - в единстве национального духа // I Оптинский форум. Наследие России и духовный выбор российской интеллигенции. Калуга - Оптина пустынь, 19-21 мая 2006 г.: сб. материалов. М.; Калуга, 2006. С. 47-52.

Трифон (Туркестанов), митр. Древнехристианские и оптинские старцы. М.: Мартис, 1996.

Флоровский, Георгий, прот. Из прошлого русской мысли. М.: «Аграф», 1998.

Флоровский, Георгий, прот. Пути русского богословия. Изд. 3-e. Paris: YMCA-PRESS, 1983.

Rozmiar artykułu: 0,6 arkusza wydawniczego 


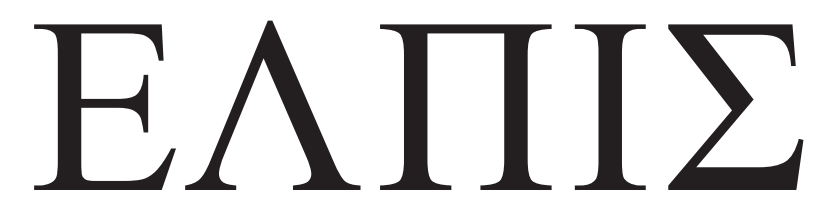

CZASOPISMO TEOLOGICZNE KATEDRY TEOLOGII PRAWOSŁAWNEJ UNIWERSYTETU W BIAŁYMSTOKU

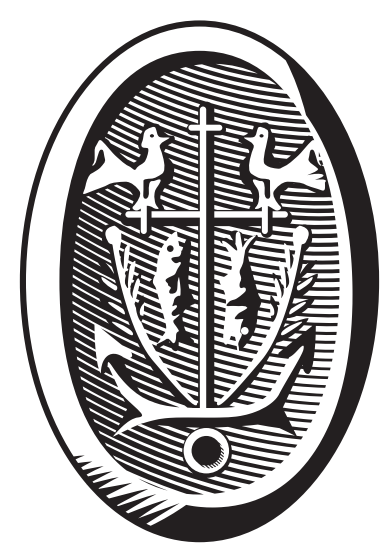

ADRES REDAKCJI

ul. Ludwika Zamenhofa 15, 15-435 Białystok, Polska tel. 85 745-77-80, e-mail: elpis@uwb.edu.pl www.elpis.uwb.edu.pl 